\title{
THE BRITISH BROADCASTING CORPORATION
}

$\mathrm{T}^{\mathrm{s}}$ HE annual roport of the British Broadcasting Corporation for the year 1963-64*, which includes those of the Broadcasting Councils for Scotland and for Wales, notes the approval by Parliament of the new Charter and the associated Licence and Agreement botween the Postmaster-General and the Corporation. Under the new Charter, the Corporation's borrowing powers have been increased to $£ 10$ million for temporary banking accommodation, instead of $£ 1$ million, and up to $£ 20$ million for capital expenditure, subject to approval by the Postmaster-General. The Broadcasting Councils for Scotland and Wales have bcen given powers in the field of tolevision similar to those which they alroady possessed in radio.

In television, throughout the year, staff and resources wore assemblod and deployed in the most complicated single operation in tho history of the Corporation. For the B.B.C. 2 oporation, an entirely new transmitter network of some sixty main stations and a large number of subsidiary stations are being planncd, some with new masts $1,250 \mathrm{ft}$. high. In many cases complete now sets of eircuits are being provided to carry the more complicated 625-line signals, and new methods of operation to maintain picture quality are being devised.

Large numbers of staff have had to bo recruited and trained while maintaining present output without any decline in standards, and this has necessitated finding and training 125 producers and many hundreds of supporting staff for programme work. On the technical side, about 900 technical staff had to be recruited and traincd, of whom some 750 specialist and operational engineering staff had already been rocruited and intograted with existing staff in good time for the opening date. The staff employed on March 31, 1964, was 19,722 full time and 1,114 part time, compared with 17,930 and 1,010 , respectively, on March 31, 1963. By November 1963, 154 enginecrs, 176 technical assistants and 189 technical opcrators had been recruited, and somo 75 trainees aro at present undergoing the sandwich-course training given to selected staff, while sorne more senior staff are taking courses for the Diploma in Technology.

Much rescarch effort was concerned with various aspects of the introduction of the 625-line television standard for B.B.C.-2, and with problems of ultra-high-frequency transmission. New equipment has been designed for use at tho Television Centre to meet the requirements of 625-line signal distribution, including pulse and timing wave-forms and signal switching, and a range of trans-

* The British Broadcasting Corporation. Annual Report and Accounts for the year 1963-64. Pp. $188+15$ photographs (Cmnd. 2508). (London: H.M.S.O., 1964.) 13s. net. istorized video amplifiers has boen dosigned which combines relative simplicity and the ability to meet all requiroments at a fraction of the cost of valve type of cquipment. Much effort has gone into colour trans. mission, including an investigation of the threo systems proposed for the transmission of colour signals.

A fully-transistorized froquency-modulated sound translator for very-high-frequency relay stations has been produced which is much casier and cheaper to maintain than the valve-type translators proviously used. The furst fully transistorjzed sound control desks designed by B.B.C. engineers have bcen installed at Broadcasting House, London. The possible future of stereophonic broadeasting in Britain has been reviewed, taking into account the results of the experimental work done, the response to experimental transmissions and the introduction of such broadcasting in the United States and in Canada. The Corporation believes that stereophony can give a worth-while improvement in reproduction, especially of music, and that there is a substantial demand for it. No definite plans can be made for its introduction, however, until a decision is reached on the system to be usod.

The report emphasizes the need for a substantial reinforcement of the technical resources of the B.B.C.'s external services in the form of rolay stations which will improve signal strength, and enable the British voice to be heard more widely and clearly. The Corporation, which was first in 1950, is now in fourth place in the number of receivers in tho world, following the United States, the U.S.S.R., and China? but West Germany is drawing up steadily. In reputation and effectivenoss, however, the Corporation more than holds its own, but the statisties given in the report demonstrate vividly how the rival systems, large and small, regard external broadcasting as of national importance, to be supported and strengthened. During tho year, it is noted that jamming of B.B.C. services to Eastern and Central Europe came to an end, and this probably marks the end of an era in East-West broadcasting.

The failure to reach agreemont on the morits of the three competing systems has deprived the Corporation of the possibility of introducing a colour service before early 1967. Since the report appeared, the International Radio Consultative Commi ${ }_{6}$ tee has met in Vienna, but once again agroement was not reached.

On finance the report rofors to the inadequacy of the licence fees for tolovision and radio and the difficulty in obtaining sufficient income to finance adoquate services, with the result that the Corporation is being forced into extensive borrowing.

\section{THE NATIONAL ELECTRONICS RESEARCH COUNCIL}

$\mathrm{T}$ HE first issue of the N.E.R.C. Review appeared in January*. The journal is a quarterly review of progross in olectronics research published by the National Electronics Research Council.

In a foreword by the chairman of the Council, Earl Mountbatton, readers are rominded that tho National Electronics Research Conncil was formed to fucilitate understanding and oxchange of ideas among all engaged in olectronics rescarch, and that it is only by such exchange

* N.E.R.C. Review, 1, No. 1 (Tanuary, 1965). A quarterly review of progresg in elcctronies researeh. Fdited by Graham D. Clifford. Pp. 1-20 +iv, (London: National Electronios Research Council, 1965.) 108. that any form of co-ordination in research can be achieved in industry, the universities, colloges of advanced tochnology and Governmental research establishments. $\mathrm{He}$ goos on to state that the purpose of tho review will be to record facts concorning the activities of the Council, to publish briof accounls of such projects as have bcon initiated and to comment generally on research achievement and on work in progress.

The longest article deals with the Counoil's proposnl to investigate the systom known as 'S.D.I.', the selective dissemination of information. Recognizing the importance and urgency of the problem of keeping the research 